\title{
SOSIOLOGI HUKUM ISLAM \\ (Analisis Terhadap Pemikiran M. Atho' Mudzhar)
}

\author{
M. Rasyid Ridla \\ (STAIN Pamekasan dan peserta Program Doktor \\ IAIN Sunan Ampel Surabaya)
}

\begin{abstract}
Abstrak: Sebagai sesuatu yang tidak muncul eksis dalam ruang hampa, jelas, hukum Islam merupakan fenomena budaya dan fenomena sosial sekaligus. Kenyataan ini menyadarkan kita bahwa dalam melakukan studi hukum Islam, penggunaan perspektif ilmu-ilmu budaya dan ilmuilmu sosial merupakan suatu keniscayaan dalam meneropong hukum Islam. Artikel ini, berusaha memotret gagasan M. Atho' Mudzhar tentang sosiologi hukum Islam, yang dapat mengambil beberapa tema yakni studi mengenai pengaruh agama terhadap perubahan masyarakat, studi tentang pengaruh struktur dan perubahan masyarakat terhadap pemahaman ajaran agama atau konsep keagamaan, studi tentang tingkat pengamalan beragama masyarakat, studi tentang pola sosial masyarakat Muslim dan studi tentang gerakan masyarakat yang membawa paham yang dapat melemahkan atau menunjang kehidupan beragama.
\end{abstract}

Kata Kunci: Sosiologi Hukum Islam, Islam sebagai fenomena sosial, Islam sebagai fenomena budaya.

\section{Pendahuluan}

Upaya untuk merumuskan metodologi studi Islam bukanlah merupakan fenomena baru abad modern sekarang ini. Kesadaran tentang urgensi metodologi yang akurat tentang mempelajari Islam telah dimulai sejak masa sejarah Islam klasik. Diantara bukti yang menegaskan hal tersebut adalah munculnya beragam disiplin ilmu dalam Islam seperti ilmu hadith dengan segala percabangannya, ilmu 


\section{Rasyid Ridla}

ushul fiqh dan berbagai disiplin lainnya, yang sayangnya, ilmu-ilmu itu masih terasa terserak-serak sehingga deskripsi metodologi studi Islam yang utuh belum tampak. Karena itu, upaya pengembangan metodologi studi Islam sekarang ini, selain harus mengakomodasi pemikiran-pemikiran baru -termasuk juga yang mungkin datang dari Barat-juga mesti selalu menyertakan pemikiran-pemikiran metodologi yang telah lama ada namun masuk berserak itu.

Tulisan ini berusaha memotret gagasan M. Atho' Mudzhar tentang urgensi pendekatan sosiologi dalam mengkaji hukum Islam, sehingga diharapkan nantinya bisa dimengerti jika terdapat produk ijtihad tentang hukum Islam, namun tidak lazim, akan tetapi jika dilihat dari perspektif keilmuan [sosiologi misalnya], fenomena tersebut merupakan suatu kelaziman, dikarenakan adanya dinamika sosial.

\section{Agama sebagai Fenomena Budaya dan Fenomena Sosial}

Sebelum memasuki substansi permasalahan tentang hukum Islam dalam perspektif sosiologis, dalam perspektif M. Atho' Mudzhar ${ }^{1}$ memandang perlu untuk dikaji terlebih dahulu agama sebagai fenomena budaya dan agama sebagai fenomena sosial, dengan maksud untuk memperjelas fokus pengkajian.

Pada awalnya, ilmu (science) diklasifikasikan menjadi dua macam, ilmu alam dan ilmu budaya. Ilmu alam bertugas mencari

\footnotetext{
${ }^{1}$ H. M. Atho' Mudzhar, dilahirkan di Serang, Propinsi Banten, 20 Oktober 1948. Menamatkan sarjana lengkap tahun 1975 di IAIN Jakarta. Tahun1978 melanjutkan studi di University of Queensland, Brisbane, Australia hingga memperoleh Gelar Master of Social and Development pada tahun 1981. Tahun 1986 mempelajari Islam di University of California Los Angeles (UCLA) hingga memperoleh gelar Doctor of Philosophy dan Islamic Studies pada tahun 1990. Sepulangnya dari Amerika, beliau menjadi birokrat dengan menjabat sebagai Direktur Pembinaan Pendidikan Agama Islam pada sekolah Umum dan selanjutnya Direktur Peembinaan Perguruan Tinggi Agama Islam Departemen Agama. Sejak Oktober 1996 beliau menjabat Rektor IAIN Sunan Kalijogo Yogyakarta hingga tahun 2000. Ketika menjadi rektor itulah, beliau banyak berkecimpung dalam dunia keilmuan dengan aktif memberi kuliah di program pascasarjana, yang puncaknya pada 15 September 1999 beliau dikukuhkan sebagai profesor dalam ilmu Sosiologi Hukum Islam di IAIN (sekarang UIN Yogyakarta). Pasca menjabat sebagai rektor, hingga sekarang ini beliau menduduki posisi sebagai Kepala Balai Penelitian, Pengembangan, Pendidikan dan Latihan (BALITBANG DIKLAT) Departemen Agama RI.
} 


\section{SOSIOLOGI HUKUM ISLAM (Analisis Terhadap Pemikiran M. Atho' Mudzhar)}

hukum-hukum alam, mencari keteraturan yang terjadi pada alam yang dilakukan dengan mengurai keterulangan suatu fenomena alam. ${ }^{2}$ Sebaliknya pengetahuan budaya, bersifat tidak terulang, melainkan unik. ${ }^{3}$

Diantara ilmu pengetahuan kealaman dan pengetahuan budaya itu terdapat ilmu pengetahuan sosial. Ilmu-ilmu sosial berusaha mencoba memahami fenomena yang tidak berulang tetapi dengan cara memahami keterulangannya, sehingga penelitian ilmu sosial mengalami problem dari segi obyektivitasnya. ${ }^{4}$

Kemudian, dimanakah letak studi-studi agama [Islam] ?. Jika dilihat dari definisi yang sering dikemukakan yakni agama sebagai kepercayaan akan adanya sesuatu yang Maha Kuasa dan hubungan dengan yang Maha Kuasa itu, maka agama adalah gejala budaya, karena agama adalah kepercayaan. Sedangkan interaksi antara sesama pemeluk agama adalah gejala sosial. Dengan demikian, agama dapat dilihat secara bipolar, yakni sebagai gejala budaya dan sebagai fenomena sosial. ${ }^{5}$

\footnotetext{
${ }^{2}$ Misalnya jika kemarin air mengalir dari atas ke bawah, sekarang dan besok juga demikian. Keterulangan gejala tersebut dapat diamati dan dites kembali oleh peneliti berikutnya, sehingga inti ilmu kealaman adalah berusaha memahami keterulangan pada fenomena alam, sehingga ia bersifat positivisme, artinya sesuatu baru dianggap sebagai ilmu jika observable, measurable dan verifiable. Periksa M. Atho' Mudzhar, Pendekatan Studi Islam. (Yogyakarta: Pustaka Pelajar, 1998), 13.

${ }^{3}$ Misalnya pengetahuan tentang batu nisan seorang raja atau arsitektur istananya adalah unik untuk batu nisan dan istana tersebut. Demikian pula pengetahuan sejarah tentang suatu dinasti adalah unik untuk dinasti tersebut. Pengetahuan tentang hal tersebut [batu nisan, arsitektur istana dan sejarah dinasti] adalah unik untuk obyek yang dideskripsikannya dan telah dianggap memadai dengan cara memandangnya demikian, meskipun tidak terulang.

${ }^{4}$ Karena itu, sebagian pakar ilmu sosial menggunakan ilmu statistik dalam porsi yang besar agar dapat mengukur gejala sosial secara lebih cermat dan lebih ajeg, sehingga lahirlah ilmu sosial kuantitatif; sebaliknya ada pula pakar sosial yang mengembangkan ilmu sosial yang lebih dekat dengan ilmu budaya seperti antropologi sosial. Periksa M. Atho' Mudzhar, "Pendekatan Sosiologi Dalam Studi Hukum Islam", dalam M. Amin Abdullah, et.al., mencari Islam: Studi Islam dengan Berbagai Pendekatan. (Yogyakarta: Tiara Wacana, 2000), 29.

${ }^{5}$ Dalam kaitannya dengan Islam, Islam biasanya didefinisikan sebagai wahyu Allah yang diturunkan kepada Muhammad untuk kebahagiaan dunia akhirat. Sebagai wahyu, Islam berarti ajaran dan sebagai ajaran berarti Islam sebagai gejala budaya. Ketika seseorang mempelajari bagaimana ajaran Islam tentang shalat, puasa, haji,
} 


\section{Rasyid Ridla}

Hal ini berarti. Studi Islam dapat didekati dari perspektif fenomena budaya dan dapat pula dari perspektif fenomena sosial atau keduanya sekaligus. Ketika Islam dilihat sebagai gejala budaya, maka metodologi yang digunakan adalah metode penelitian budaya, seperti filsafat, sejarah, studi naskah dan arkeologi. Dan ketika Islam dilihat sebagai gejala sosial, maka metodologi yang digunakan adalah metode penelitian ilmu-ilmu sosial. Kemudian, penggunaan studi Islam sebagai fenomena budaya dan fenomena sosial sekaligus, dapat dilihat dari obyek studi tentang fatwa ulama dan situasi politik yang mengitarinya ${ }^{6}$

\section{Format Studi Islam dengan Pendekatan Sosiologi}

Studi Islam dengan pendekatan sosiologi, dalam pandangan Atho' Mudzhar lebih mendekati kajian sosiologi agama klasik dari pada sosiologi agama modern, dengan alasan studi Islam dalam perspektif sosiologis mempelajari hubungan timbal balik antara agama dan masyarakat. ${ }^{7}$

Lebih lanjut, Atho Mudzhar menyatakan bahwa studi Islam dengan pendekatan sosiologi dapat mengambil, setidaknya lima tema: ${ }^{8}$ Pertama, studi mengenai pengaruh agama terhadap perubahan masyarakat. Tema ini, mengingatkan kita pada Emile Durkheim yang

tentang konsep keesaan Tuhan, tentang argumen adanya Tuhan, tentang aturan etika dan aspek lainnya, berarti ia mempelajari Islam sebagai gejala budaya. Sedangkan hubungan antara sesama pemeluk Islam dalam mengamalkan ajaran agamanya dan hubungan antara pemeluk Islam dengan pemeluk agama lain adalah gejala sosial

6 Ketika studi tersebut membahas argumen-argumen nash suatu fatwa dan pembahasan tentang hal tersebut dalam naskah kitab fiqh klasik, berarti sedang melihat fatwa tersebut sebagai gejala budaya, tetapi ketika studi tersebut membahas faktor sosial politik yang mempengaruhi penafsiran para ulama tentang dalil-dalil tersebut berarti sedang melihat Islam sebagai gejala sosial. Diskusi lebih lanjut tentang hal ini periksa M. Atho' Mudzhar, Fatwa-Fatwa Majelis Ulama Indonesia. (Jakarta: INIS, 1993)

${ }^{7}$ studi Islam dengan pendekatan sosiologi merupakan bagian dari sosiologi agama. Terdapat perbedaan tentang tema pokok antara sosiologi klasik dan modern. Dalam sosiologi agama klasik tema pokoknya adalah hubungan timbal balik antara agama dan masyarakat, bagaimana agama mempengaruhi pemikiran dan pemahaman keagamaan masyarakat. Sedangkan sosiologi agama modern, tema pusatnya hanya satu arah, yakni bagaimana agama mempengaruhi masyarakat. Lebih jelas periksa Ian Robertson, Sociology, (New York: Worth Publisher, 1982), 403.

${ }^{8}$ Mudzhar, "Pendekatan Sosiologi", 30. 


\section{SOSIOLOGI HUKUM ISLAM (Analisis Terhadap Pemikiran M. Atho' Mudzhar)}

mengenalkan konsep fungsi sosial agama. ${ }^{9}$ Dalam bentuk ini studi Islam mencoba memahami seberapa jauh pola-pola budaya masyarakat (misalnya menilai sesuatu sebagai baik atau tidak baik) berpangkal pada nilai agama, atau seberapa jauh struktur masyarakat (misalnya supremasi kaum lelaki) berpangkal pada ajaran tertentu agama atau seberapa jauh perilaku masyarakat (seperti pola berkonsumsi dan berpakaian masyarakat) berpangkal tolak pada ajaran tertentu agama. ${ }^{10}$

Kedua, studi tentang pengaruh struktur dan perubahan masyarakat terhadap pemahaman ajaran agama atau konsep keagamaan, seperti studi tentang bagaimana tingkat urbanisme Kufah telah mengakibatkan lahirnya pendapat-pendapat hukum Islam rasional a la Hanafi atau bagaimana faktor lingkungan geografis Basrah dan Mesir telah mendorong lahirnya qawl qadim dan qawl jadid imam al-Shafi'i.

Ketiga, studi tentang tingkat pengamalan beragama masyarakat. Studi Islam dengan pendekatan sosiologi dapat juga mengevaluasi pola penyebaran agama dan seberapa jauh ajaran agama itu diamalkan masyarakat. Melalui pengamatan dan survey, masyarakat dikaji tentang seberapa intens mengamalkan ajaran agama yang dipeluknya, seperti seberapa intens mereka menjalankan ritual agamanya dan sebagainya. Keempat, studi pola sosial masyarakat Muslim, seperti pola sosial masyarakat Muslim kota dan masyarakat Muslim desa, pola hubungan antar agama dalam suatu masyarakat, perilaku toleransi antara masyarakat Muslim terdidik dan kurang terdidik, hubungan tingkat pemahaman agama dengan perilaku politik, hubungan perilaku keagamaan dengan perilaku kebangsaan,

\footnotetext{
${ }^{9}$ Berdasarkan ide Durkheim, para sosiolog modern telah mengidentifikasi fungsi sosial agama, yakni fungsi solidaritas sosial, fungsi memberi makna hidup, kontrol sosial, perubahan sosial dan fungsi memberi dukungan psikologis. Periksa Robertson, Sociology, 593.

${ }^{10}$ Sebagai contoh misalnya, bagaimana ajaran Islam tentang Muhrim telah cenderung mendorong masyarakat Arab menilai bahwa kehidupan yang baik adalah yang mempraktikkan segregasi antara laki-laki dan perempuan, juga bagaimana ajaran tentang larangan riba menyebabkan banyak orang berperilaku tidak mau menyimpan uangnya di bank-bank konvensional, sehingga berkembang bank syari'ah.
} 


\section{Rasyid Ridla}

agama sebagai faktor integrasi dan disintegrasi dan berbagai senada lainnya.

Kelima, studi tentang gerakan masyarakat yang membawa paham yang dapat melemahkan atau menunjang kehidupan beragama. Gerakan kelompok Islam yang mendukung paham kapitalisme, sekularisme, komunisme merupakan beberapa contoh diantara gerakan yang mengancam kehidupan beragama dan karenanya perlu dikaji seksama. Demikian pula munculnya kelompok masyarakat yang mendukung spiritualisme dan sufisme misalnya, yang pada tingkat tertentu dapat menunjang kehidupan beragama perlu dipelajari dengan seksama pula

\section{Format Studi Hukum Islam}

Dengan mengacu pada distingsi gejala studi Islam secara umum, maka hukum Islam juga dapat dipandang sebagai gejala budaya dan sebagai gejala sosial. Filsafat dan aturan hukum Islam adalah gejala budaya, sedangkan interaksi orang Islam dengan orang lain -seagama atau tidak seagama - merupakan gejala sosial.

Secara lebih elaboratif, Atho' Mudzhar memerinci hukum Islam pada tiga segmen:

1. Penelitian hukum Islam sebagai doktrin asas. Dalam penelitian ini, sasaran utamanya adalah dasar-dasar konseptual hukum Islam seperti masalah sumber hukum, konsep maqasid al-shari'ah, qawa'id al-fiqhiyyah, tariq al-Istinbat, manhaj ijtihad dan lainnya.

2. Penelitian hukum Islam normatif. Dalam penelitian ini sasaran utamanya adalah hukum Islam sebagai norma atau aturan, baik yang masih berbentuk nas maupun yang sudah menjadi produk pikiran manusia. Aturan dalam bentuk nas meliputi ayat-ayat dan hadith ahkam. Sedangkan aturan yang sudah dipikirkan manusia antara lain berbentuk fatwa-fatwa ulama dan bentuk-bentuk aturan lainnya yang mengikat seperti kompilasi hukum Islam, dustur, perjanjian internasional, surat kontrak, kesaksian dan sebagainya.

3. Penelitian hukum Islam sebagai gejala sosial. Sasaran utamanya adalah perilaku hukum masyarakat Muslim dan masalah interaksi antar sesama manusia, baik sesama Muslim maupun dengan non Muslim. Ini mencakup masalah-masalah seperti politik perumusan dan penerapan hukum (siyasah al-Shari'ah), perilaku penegak hukum, perilaku pemikir hukum seperti mujtahid, 


\section{SOSIOLOGI HUKUM ISLAM (Analisis Terhadap Pemikiran M. Atho' Mudzhar)}

fuqaha, mufti dan anggota badan legislatif, masalah-masalah administrasi dan organisasi hukum seperti pengadilan dengan segala graduasinya dan perhimpunan penegak serta pemikir hukum seperti perhimpunan hakim agama, perhimpunan studi peminat hukum Islam, lajnah-lajnah fatwa dcari organisasiorganisasi keagamaan dan lembaga-lembaga penerbitan atau pendidikan yang menspesialisasikan diri atau mendorong studistudi hukum Islam. Dalam jenis penelitian ini juga tercakup masalah-masalah evaluasi pelaksanaan dan efektivitas hukum, masalah pengaruh hukum Islam terhadap perkembangan masyarakat atau pemikiran hukum, sejarah perkembangan hukum, sejarah pemikiran hukum, sejarah administrasi hukum serta masalah kesadaran dan sikap hukum masyarakat. ${ }^{11}$

Ketiga bentuk studi hukum Islam tersebut, lanjut Atho', dapat dilakukan secara terpisah dan dapat pula dilakukan secara bersamasama untuk melihat keterkaitan satu sama lain mengenai masalah hukum Islam. Dua bentuk studi hukum Islam yang pertama [studi hukum Islam sebagai doktrin asas dan studi hukum Islam normatif] dapat digabungkan dan diidentifikasi sebagai studi hukum Islam doktrinal, sedangkan bentuk studi hukum yang ketiga disebut sebagai studi hukum Islam Sosiologis. Dua bentuk studi yang pertama melihat Islam sebagai fenomena budaya dan bentuk studi Islam yang ketiga melihat Islam sebagai fenomena sosial.

Lebih lanjut, Atho' menegaskan bahwa seperti halnya penggunaan pendekatan sosiologis dalam studi Islam secara umum, penggunaan pendekatan sosiologi dalam studi hukum Islam dapat mengambil beberapa tema sebagai berikut:

1. Pengaruh hukum Islam terhadap masyarakat dan perubahan masyarakat. Contohnya bagaimana hukum ibadah haji yang wajib telah mendorong ribuan umat Islam Indonesia setiap tahun berangkat ke Mekah dengan segala akibat ekonomi, penggunaan alat transportasi dan organisasi managemen dalam penyelenggaraannya serta akibat sosial dan struktural yang terbentuk pasca menunaikan ibadah haji.

\footnotetext{
${ }^{11}$ Mudzhar, “Pendekatan Sosiologi”, 34-35.
} 


\section{Rasyid Ridla}

2. Pengaruh perubahan dan perkembangan masyarakat terhadap pemikiran hukum Islam. Contohnya, bagaimana oil booming di negara-negara teluk dan semakin mengentalnya Islam sebagai ideologi ekonomi di negara-negara tersebut pada awal tahun 1970-an telah menyebabkan lahirnya sistem perbankan Islam, yang kemudian berdampak ke Indonesia dengan terbentuknya bank-bank shari'ah.

3. Tingkat pengamalan hukum agama masyarakat, seperti bagaimana perilaku masyarakat Islam mengacu pada hukum Islam.

4. Pola interaksi masyarakat di seputar hukum Islam, seperti bagaimana kelompok-kelompok keagamaan dan politik di Indonesia merespons berbagai persoalan hukum Islam seperti terhadap Rancangan Undang-Undang Peradilan Agama, boleh tidak wanita menjadi pemimpin negara dan sebagainya.

5. gerakan atau organisasi kemasyarakat yang mendukung atau yang kurang mendukung hukum Islam, misalnya perhimpunan penghulu, perhimpunan hakim agama, perhimpunan pengacara dan sebagainya.

Sebagai mekanisme konkret dari tawaran pemikirannya, Atho' mengajukan beberapa contoh aplikasi pendekatan sosiologis terhadap hukum Islam, salah satunya adalah tentang Tawsiyah Majelis Ulama Indonesia (MUI) mengenai Calon Legislatif non Muslim ${ }^{12}$.

12 Isi tawsiyah tersebut adalah [1] agar bangsa Indonesia khususnya umat Islam menggunakan hak pilihnya secara benar dan bertanggung jawab sesuai kata hati nurani dengan memilih partai politik yang diyakini dapat memperjuangkan aspirasi dan kepentingan umat Islam, bangsa dan negara. [2] agar umat Islam dengan ikhlas dan niat ibadah kepada Allah memilih salah satu dari partai politik yang secara sungguh-sungguh menonjolkan caleg-caleg yang beragama Islam dan berakhlak karimah. [3] agar umat Islam mewaspadai kebangkitan kembali bahaya komunisme dan kekuasaan otoriter dan sekuler melalui partai politik peserta Pemilu yang pada dasarnya menyimpan kebencian kepada Islam dan kejayaan negara Republik Indonesia. [4] agar umat Islam senantiasa berserah diri kepada Allah memperbanyak do'a munajat agar pemilu berlangsung aman, demokratis Luber dan Jurdil sehingga bangsa Indonesia dapat keluar dari berbagai krisis menuju terwujudnya masyarakat Indonesia baru di bawah naungan ridha Allah swt. Tawsiyah ini tertanggal 1 Juni 1999 ditandatangani oleh KH. Ali Yafie dan Drs, Nazri Adlani. Periksa Majalah Mimbar Ulama (Jakarta: MUI Pusat, Rabi’ul Awal 1420 H/ Juni 1999), 27. 


\section{SOSIOLOGI HUKUM ISLAM (Analisis Terhadap Pemikiran M. Atho' Mudzhar)}

Sehubungan dengan contoh pertama, Atho' menegaskan bahwa substansi tawsiyah tersebut merupakan suatu problem hukum Islam, sebab kitab-kitab fiqh (yurisprudensi Islam) umumnya memuat hal yang berkaitan dengan tata politik kenegaraan yang disebut dengan kitab al-Qada', artinya bab tentang kehakiman yang bagiannya termasuk masalah kekuasaan dan kepemimpinan. Kemudian mengingat tawsiyah tersebut merupakan himbauan, apakah menjadi problem hukum dan bukan sekedar problem moral?

Dalam konteks ini, Atho' menyatakan bahwa dalam hukum positif, himbauan belum merupakan persoalan hukum, karena suatu perbuatan baru dapat berkategori hukum jika perbuatan itu mengikuti atau melanggar aturan hukum tertentu yang mempunyai sanksi. Akan tetapi dalam hukum Islam, himbauan atau anjuran merupakan perbuatan hukum, dengan alasan hukum dalam Islam bukan hanya berkaitan dengan taat atau melanggar aturan tertentu yang ada sanksinya, akan tetapi juga berkaitan dengan moral. Bukankah kita mengenal adanya konsep sunnah dan makruh. Meskipun dalam perspektif hukum positif, keduanya [sunnah dan makruh] tidak berkategori hukum, akan tetapi dalam perspektif Islam berkategori hukum, karena substansi hukum dalam perspektif Islam mencakup substansi hukum tetapi juga moral. ${ }^{13}$

Kemudian berkaitan dengan isi tawsiyah tersebut, Atho' menegaskan bahwa ketika MUI mengeluarkan himbauan agar umat Islam Indonesia tidak memilih partai politikdalam pemilu yang kebanyakan calon legislatifnya non Muslim, sesungguhnya ayat-ayatQur'an tersebut di atas itulah [QS. Ali Imran ayat 28] yang menjadi acuan para pimpinan MUI. Inilah rambu-rambu nilai yang bersifat doktrinal yang mendasari himbauan MUI tersebut. ${ }^{14}$

\footnotetext{
${ }^{13}$ Lebih jauh hukum Islam berada pada posisi tarik menarik antara hukum dan moral. Adanya konsep hilah (hiyal) dalam fiqh dan ushul fiqh adalah bukti tentang posisi itu. Bahkan, sesungguhnya hukum Islam itu bukan hanya berada pada tarik menarik sekitar moral dan hukum, tetapi juga tarik menarik antara kesatuan dan keragaman, universalisme dan partikularisme, wahyu dan akal, antara otoritarian dan liberal. Lebih lanjut periksa Noel J. Coulson, Conflicts and Tensions in Islamic Jurisprudence. (Chicago: The University of Chicago Press, 1969).

${ }^{14}$ Mudzhar, "Pendekatan Sosiologi", 42.
} 


\section{Rasyid Ridla}

Kemudian secara sosiologis, logika MUI dalam tawsiyah tersebut dapat diamati, yakni himbauan itu dikeluarkan beberapa saat menjelang pelaksanaan pemilu yang akan memilih wakil dan pemimpin rakyat yang membuat Undang-Undang baru dan mengamandemen UU lama. Jika wakil rakyat tersebut kebanyakan tidak beragama Islam, bagaimana mungkin mereka memperjuangkan aspirasi umat Islam. Dengan alur logika demikian, kiranya dapat dimengerti.

Dalam konteks demikian, kita melihat bahwa MUI dihadapkan pada realitas empirik yang harus dijawab yakni bahwa ada diantara partai politik peserta pemilu yang secara lahiriah berasaskan kebangsaan, tetapi calon legislatifnya didominasi oleh non Muslim yang berarti tidak mencerminkan representasi bangsa Indonesia. MUI tidak ingin umat Islam dikelabui, sehingga keluarlah tawsiyah tersebut. MUI tidak mengingkari hak non Muslim untuk menjadi anggota legislatif di negara ini, tetapi hendaknya jangan sampai mendominasi dan mengatasnamakan sebagian besar rakyat yang justru beragama Islam. Dari segi itu, pikiran hukum MUI tentang kepemimpinan non Muslim sesungguhnya telah mengalami kompromi, dibandingkan dengan larangan al-Qur'an yang mutlak sama sekali melarang mengangkat pemimpin non Muslim. Dalam konteks ini landasan hukum doktrinal ${ }^{15}$ MUI telah disesuaikan dengan realitas empirik masyarakat.

Dari uraian di atas, dapat ditegaskan bahwa tawsiyah MUI menjelang pemilu 7 Juni 1999 merupakan hasil ijtihad yang telah

\footnotetext{
${ }^{15}$ Dalam literatur hukum Islam terdapat perbedaan di kalangan ulama tentang boleh tidaknya berkoalisi dengan orang kafir pada saat perang. Madhab Maliki melarang mutlak, sebagaimana dinyatakan dalam surat Ali Imran ayat 28. asbab al-Nuzul ayat tersebut berkaitan dengan kasus Ubadah bin Shamit --Muslim Anshar-yang mempunyai perjanjian tolong menolong dengan seorang Yahudi yang mengaku dapat mengerahkan 500 orang Yahudi untuk menakuti musuh Islam dalam perang Ahzab. Ubadah bertanya pada Nabi tentang tindakannya, dan turunlah ayat tersebut. Sedangkan jumhur ulama -madhab Shafi'I, Hanbali dan Hanafi-berpendapat boleh berkoalisi dengan orang non Muslim dengan syarat, pertama, jika memang benarbenar diperlukan, kedua, dapat dipercaya. Pendapat ini berdasarkan perbuatan Nabi yang pernah meminta bantuan seorang Yahudi dari Bani Qaynuqa' dan pernah juga meminta bantuan pada Safwan bin Uyaynah dari Bani Hawazin. Periksa Muhammad Ali al-Shabuni, Rawai' al-Bayan fi TafsirAyat al-Ahkam min al-Qur'an. (Kairo: Dar al-Qur'an al-Karim, 1972), 402-403.
} 


\section{SOSIOLOGI HUKUM ISLAM (Analisis Terhadap Pemikiran M. Atho' Mudzhar)}

mengakomodasi realitas bahwa tidak mungkin semua wakil rakyat di DPR itu Muslim, tetapi bagi MUI hendaknya yang non Muslim itu tidak dominan jumlahnya.

Analisis

Dari deskripsi di atas, dapat dinyatakan bahwa situasi kondisi sosial politik yang mengitari suatu ijtihad sedemikian berpengaruh signifikan terhadap hasil ijtihad tersebut. Dalam konteks demikianlah inilah, pendekatan sosiologis dalam studi hukum Islam sedemikian urgen untuk dilakukan, bahkan tidak hanya mencakup masalahmasalah hukum Islam kontemporer, tetapi juga masalah-masalah hukum Islam masa klasik, seperti yang dicontohkan oleh David S. Powers. Dalam studi tersebut, Powers mendemonstrasikan bagaimana hukum Islam waris dipahami orang sekarang, berbeda dan telah bergeser dari apa yang ada pada zaman nabi dan para sahabat besar (proto Islamic Law) serta masalah-masalah yang berkaitan dengan pergeseran-pergeseran tersebut. 16

Penerapan pendekatan sosiologi dalam studi hukum Islam berguna untuk memahami secara lebih mendalam gejala-gejala sosial di seputar hukum Islam, sehingga dapat membantu memperdalam pemahaman hukum Islam doktrinal dan pada gilirannya membantu dalam memahami dinamika hukum Islam. Dari contoh yang dikemukakan di atas, tampak jelas bahwa perkembangan pemikiran hukum Islam acap kali dipicu -bahkan diarahkan-oleh perbenturan kepentingan antar kelompok dalam masyarakat yang berinteraksi. Hal ini memberi kesan bahwa -sampai batas tertentu-hukum Islam hanyalah produk pemikiran manusia Muslim dalam meresponsi lingkungan sekitarnya. Untuk sebagian hal itu benar adanya, tetapi pada saat yang sama juga merupakan ekspressi upaya dalam memahami dan menjabarkan titah kewahyuan dalam realitas aktual. Dalam konteks tarik menarik antara titah kewahyuan transendental dengan realitas aktual empirikal itulah terletak dinamika hukum Islam serta disini pula letak kontribusi signifikan studi hukum Islam dengan bingkai pendekatan sosiologi.

\footnotetext{
${ }^{16}$ Periksa David S. Powers, Studies in Qur'an and Hadith: The Formation of Islamic Law of Inheritance. (Berkeley: University of California Press, 1986). Lihat juga M. Atho' Mudzhar, Membaca Gelombang Ijtihad: Antara Tradisi dan Liberasi. (Yogyakarta: Titian Ilahi Press, 1998).
} 


\section{Rasyid Ridla}

Pada aras inilah tampaknya -jika diamati secara jeli-Atho' Mudzhar mendedikasikan hampir keseluruhan energi intelektualnya, sebagaimana tampak dalam hampir keseluruhan karya tulis dan hasil penelitiannya.

Wa Allah a'lam. 